\title{
Let's Create a Harmonious and Peaceful World through Quality Bilingual Education! Indigenous Tsotsil Children and Their Languages the Solution!
}

\author{
Karla B. Del Carpio \\ World Languages and Cultures Department, University of Northern Colorado, United States
}

\begin{abstract}
The purpose of this paper is to underline the implications that language endangerment has, not only for the speakers of a specific language, but for the entire world as losing a language involves the disappearance of cultural, spiritual and intellectual knowledge as well as cultural identity. Many indigenous languages in Mexico, for example, have been in danger as Spanish, the dominant language of the country, has put them at a disadvantage. Transitional bilingual education has been used to achieve such a goal. Since this has been the case, some indigenous communities have taken the initiative to work diligently to preserve and promote their native language and culture despite the sociopolitical, economic and educational pressures they face. An example of that is the Mayan Tsotsil community in Chiapas in southern Mexico. This paper offers a summary of the findings of the qualitative research study that was conducted to explore the situation of the Tsotsil language at a Spanish-Indigenous Tsotsil elementary bilingual school in Chiapas. Tsotsil children and their teacher show that it is possible to preserve and promote the Tsotsil language when working together as a community. It is concluded that quality bilingual education and inclusive schools can be great tools that can contribute to have a harmonious and peaceful world.
\end{abstract}

Index Terms - Indigenous Tsotsil, children, elementary bilingual education, Chiapas, Mexico

\section{INTRODUCTION}

\section{A. Let's Enrich Ourselves and Our World!}

Costas (2018) reminds us that:

Humanity has a rich, beautiful, varied and necessary linguistic heritage which is under risk of disappearance due to different reasons such as disrepute and ignorance based on an expansionist, supremacist and predatory ideology that surround communities that do not speak "international languages" (99\% of the languages of the world). As a result, diversity is razed, and an assimilationist and impoverishing monoculture is implanted leaving us with only two or three languages wrongly called "universal" when in reality all languages are universal (p. 3).

Costa's (2018) words show how linguistic imperialism has prevailed and invaded the world which is a situation that has negatively affected different communities, their languages and cultures globally resulting in a significant loss not only for those communities, but for the entire world. Therefore, it can be said that our world has been characterized by losing rather than by gaining/winning as losing a language involves the disappearance of cultural, spiritual and intellectual knowledge as well as cultural identity. Woodbury (2012) argues that when a language dies, we lose "prayers, myths, ceremonies, poetry, oratory, and technical vocabulary to everyday greetings, leave-takings, conversational styles, humor, ways of speaking to children, and terms for habits, behaviors, and emotions" (p. 13). Sadly, traditions disappear, and, in some cases, they are replaced by the traditions of the dominant society.

On the other hand, many times indigenous languages have wrongly been considered as not being capable to accommodate new communication needs as they are perceived as "not being enough." This is a subjective perception based on a language deficit ideology that reflects the vision of many dominant societies all over the world. Such ideology as well as the practices based on it have had a negative impact on indigenous peoples, their languages and cultures. Since this has been the case, some indigenous communities have taken the initiative to work diligently to preserve and promote their native language and culture despite the sociopolitical, economic and educational pressures they face. An example of that is the Mayan Tsotsil community in Chiapas, Mexico. In order to contextualize the situation of the Tsotsil peoples, their language and culture and the qualitative research study that was conducted to explore the situation of the Tsotsil language at a Spanish-Tsotsil elementary bilingual school in Chiapas, the section below is focused on Mexico's indigenous languages and their current situation.

\section{B. Mexico}

The Mexican nation is the third largest country in Latin America, after Brazil and Argentina. Mexico is known for having a society characterized by extremes of wealth and poverty, with a small group of people who are middle class. 
On the other hand, Mexico is also known for having a high level of cultural and linguistic diversity thanks to the strong presence of indigenous peoples in the nation. Although Spanish is the dominant language of Mexico, there are also approximately "11 linguistic families, 68 linguistic groups and 364 linguistic varieties" (Villegas, 2011, para. 3). Nonetheless, the survival of these languages is not guaranteed due to the lack of intergenerational transmission as well as their lack of use in the media, in education and other formal settings. Also, majority and more "prestigious" languages such as English and French are favored and encouraged to be learned rather than indigenous languages. In Mexico as in other countries, learning "international" and "powerful" languages is seen as increasing educational and employment opportunities which is an example of how languages are not treated equally in society. This confirms that speaking a language that is viewed as high in status gives some people the advantage not only in a specific society, but in the world at large, that is, it gives privilege to a certain group of people which can facilitate their access to social, political and educational institutions as well as access to different forms of capital. In addition, language privilege may increase the possibilities of being perceived "positively" in society. Unfortunately, most indigenous peoples in Mexico, as in different parts of the world, have not had this language privilege. In contrast, they have been discriminated against, have been excluded from society and their human rights have been violated. The stigma indigenous peoples have suffered, and with that their languages and cultures, have placed indigenous languages in danger.

According to the National Commission for the Development of Indigenous Peoples in Mexico (2014 as cited in Del Carpio, 2017):

Today's Mexico is still far from being a real multicultural nation. It is recognized as a pluricultural nation based on its native peoples, but it is still not a state-nation that accepts and fully promotes, as part of its conditions, the diversity and the many identities originated in the indigenous cultures that coexist in a territory of approximately two millions of square kilometers (p. 21).

Although indigenous peoples have a strong presence in Mexico, they are still given the title of "minorities"; minorities that have been deprived of what belongs to them such as their lands, traditions, etc. Therefore, the question that some Tsotsil peoples have is if their language will also be taken from them (Del Carpio, 2012). In order to explore the situation of the Tsotsil language, a qualitative research study was conducted with young Tsotsil students and their teacher.

\section{THE STUDY}

Everything has been taken from us. All we have left is our indigenous language. Are they also going to take that away from us? (Indigenous teacher, Del Carpio, 2012).

\section{Methodology}

This research was conducted at a Spanish-Tsotsil elementary bilingual school in Tentic, Chiapas in southeast Mexico. The school has 1 principal, 8 teachers and 227 students who are mostly Tsotsil children. The school was founded in 1990 and is located in Tentic, which is a small town that belongs to the municipality of Chamula in the State of Chiapas (Del Carpio, 2017). The aim of this ethnographic research was to study the situation of the indigenous Tsotsil language by focusing on a Spanish-Tsotsil elementary bilingual school in order to know how bilingual education helps or hinders the preservation of the Tsotsil language. The researcher lived in the indigenous community and over the course of one semester 30 Tsotsil third graders were observed passively and actively in the classroom and other areas of the school. Students were also interviewed in small groups and their teacher was observed passively when teaching and was interviewed during the semester. The school principal was also interviewed multiple times.

\section{DisCUSSION OF RESEARCH FINDINGS}

\section{A. Chiapas}

The school where this research was conducted is located in Chiapas which is a state in southern Mexico and is the home of 322274 indigenous peoples (Estadística de Población de Chiapas, 2014). For this reason, Chiapas is known for being one of the states with the highest rates of indigenous population in the country. As a result, the level of cultural and linguistic diversity is also high. Guitart (2006) points out that there are 8 linguistic groups in the region, that is, Tzeltal, Tsotsil, Choles,Tojolabales, Kanjobales, Mames and Chujs. INEGI (2010) states that the Tsotsil language has approximately 417462 speakers. Nonetheless, historically, transitional bilingual education in favor of the Spanish language has placed the Tsotsil language at a disadvantage. For this reason, "education" has been considered a weapon that has forced indigenous children to assimilate to the dominant language and society as a way to help them "modernize" (Bessant, 2013). Nonetheless, the participants of this research have resisted to abandon their native language by findings ways to maintain it and promote it at school.

\section{B. Tsotsil Children as Active Agents of Language Preservation and Promotion}

As stated earlier, historically, elementary Spanish-Indigenous bilingual programs in Mexico have been used to spread Spanish at the expense of indigenous languages. As a result, passing indigenous language onto younger generations has not always been possible which significantly affects the preservation of these languages as interegenerational 
transmission is fundamental for a language to survive. Caminal, Cappellari and Di Paolo (2018) underline the key role that parents play to transmit a language to their children. Some parents "may be inclined to transmit the language that embodies their cultural heritage or their ethnic identity. Immigrant parents, for example, may consider passing on the host-country language to foster their children's integration, shelter them from discrimination, and ultimately improve their economic outcomes in the long-run" (p. 3). Caminal, Cappellari and Di Paolo (2018) argue that:

Previous studies have focused on immigrants in societies with a predominant language. Clearly, parents also face non-trivial language choices in environments in which there is more than one language that cannot be considered a "minority" language. There, the key issues are not so much related to the speed of assimilation, but to the economic value of bilingualism, the level of endogamy of different speech communities, and the long-run contest between competing languages for dominance (p. 3).

It is true that when native and national languages are under the roof of mainstream society, the indigenous language is at a disadvantage particularly when boundaries are unclear. In this regard, Francis and Reyhner (2002 as cited in Del Carpio, 2017) point out that when indigenous and national languages "compete" for space, and when the "boundaries" between using one or the other are not clear, this imbalance puts the indigenous language at a disadvantage" (p. 101). This has also been the case of the Tsotsil language, that is, it has had to compete against the Spanish language. For this reason, the Tsotsil participants of this research have taken the initiative to take action to preserve and promote the Tsotsil language at school despite the fact that there is little support from the government and educational institutions.

\section{The Situation of the Tsotsil Language at School}

The Tsotsil children, their teacher and the school principal as well as all the rest of the staff at the school have demonstrated that it is possible to implement quality bilingual education when being committed to do so and when working together as a community. Participants of this research have worked diligently for the survival and transmission of the indigenous language. At this bilingual school, Tsotsil is respected, that is, it does play an active role in the classroom and outside of it. The fact that Tsotsil is the native language of the teachers who work at the focus school as well as the students' has helped the preservation of the indigenous language. It should be stated that most of the population in the town has made the indigenous language be the dominant language in the area. This supports Reifler and Edmonson's (1984) arguments that Tsotsil is not moribund or vestigial. In other words, both the Tsotsil language and its oral traditions are omnipresent in the Highlands of Chiapas. Reifler and Edmonson's (1984) argue that most native narrative accounts of Tsotsil history emphasize the learning of Bats'i k'op and its specialized forms -such as prayer, ritual speech, and song-as the threshold of humanness in our progress through the ages.

Tsotsil is used as a language of instruction at the research school. However, its use could be increased if all the instructors received more training on how to teach with a bilingual approach. The lack of training has been a common barrier in bilingual schools. However, instructors at the research school do teach using both languages especially in fourth, fifth and sixth grades.

\section{The Uses of Tsotsil by the Instructor}

The Tsotsil language is used for different purposes, for instance, the third-grade teacher uses it to provide students with the instructions for some of the activities to be completed in the classroom as this is the language that all students understand fully. Also, the teacher speaks the native language to teach content in different subjects including Math and Spanish. Moreover, the instructor also speaks Tsotsil to check students' answers when being given a task to be completed in class. For example, it is common that the teacher asks for volunteers to write their answers on the board and then she checks the answers using Tsotsil outloud. It was interesting to observe that the Tsotsil language does have an active role in Math and Spanish which are the 2 courses that are considered to be the most important at the elementary level. Although both Spanish and Tsotsil are used when teaching Math, for example, third graders have difficulties understanding how the measurement system used by the dominant society works as the way Tsotsil indigenous communities measure is different. The instructor mentioned that Tsotsil people use "cuartadas" instead of centimeters or meters. The latter exemplifies that every culture understands the world differently which is also reflected on the language each community speaks. This also shows the need and importance of considering students' first language and culture during the learning process so that what they learn in school makes sense and is meaningful to them. Tsotsil is also used in the Spanish class both orally and in writing. For instance, students were asked to work on an activity in which the teacher asked them to use the Tsotsil language to write a poem based on the pictures of one of the readings in the book. Most students were on task while writing their poem in Tsotsil and thinking of a title for their work.

It was common to observe that students were asked to write their answers for some activities on the board. Then, the teacher would stand up next to the student to check his/her spelling. After that, the instructor asked him/her to read the sentences outloud and then she would read them outloud and had the student repeat what she said. The teacher stated that the purpose of doing that was to help students improve their reading skills and pronunciation in the Tsotsil language. Despite the spelling mistakes some third graders made when writing, it was interesting to observe them write in both Spanish and Tsotsil. Lightbown and Spada (1999) argue that language acquisition is one of the most impressive and fascinating aspects of human development and observing how this acquisition takes place at such a young age is even more fascinating. Some third graders were able to communicate in both Spanish and Tsotsil in writing, which shows 
how intelligent and talented children are as well as how skillful they are to learn and use a second language at such a young age. Their situation exemplifies what Lightbown and Spada (1999) defines as sequential bilingualism, that is, children who begin to learn a second language after they have acquired the first language. It is true that the third graders' level of proficiency in Spanish varies; however, there are some who are actually able to write and speak in basic Spanish; their L2.

Tsotsil is the main language of communication among the teacher, the students and the students' parents. It was observed that when parents visited the classroom to talk to the instructor, the conversation was carried in Tsotsil. Also, when conversations took place between parents and their children these were conducted in Tsotsil. The fact that Tsotsil is spoken by younger generations, in this case, by third graders, is an asset as it contributes to the preservation of the indigenous language. Besides, it helps maintain the relationship between the school and the home in terms of language use, which is essential. According to de Jong (2011), "the use of the students' languages in school also influences the relationship between parents and the school" (p. 34) therefore it is necessary to ensure that this relationship is reinforced by maintaining and promoting students' first language at school.

The Tsotsil language is spoken by all staff at the elementary school. When bilingual personnel are accessible, the possibilities for parents to come to school increase. Also, when homework is in the native language, parents can better assist at home.

\section{E. The Uses of Tsotsil by Children}

The first language of all the third graders who participated in this research is Tsotsil. Nonetheless, some of them also speak some Spanish, others only understand it and others do not understand it at all, which means they are monolingual in Tsotsil. The indigenous language is the language they are the most proficient in.For many indigenous children, the school is the first contact with the Spanish language, which reminds us of the importance of using students' first language and culture in their learning process at such an institution. By doing so, the possibilities of making school learners' second home would increase, which is fundamental as the school plays an essential role in the life of each individual. Hernandez (2009) declares that the school should "contribute to the formation of children so that they can develop their skills, competences, attitudes and values that allow them to know their reality, understand it and act upon it to transform it" (p. 3). In other words, what we need is a school for life. Fortunately, as stated before, the Tsotsil language and culture are embraced at the bilingual school where this research was conducted. Tsotsil is the language students feel more comfortable in and use it both inside and outside of the school. In the classroom, Tsotsil is used to communicate among peers or to work on different assigned activities. Because Tsotsil has a writing system, students also use it when writing, for instance, to write poems in class. It was observed that third graders are influenced by their first language when they speak Spanish. For example, when they speak in such a language, they use the Tsotsil intonation. This is a good example of the influence and impact that their first language has when they speak the second language. In the case of the observed Tsotsil children, the use of the Tsotsil intonation when speaking in Spanish did not interfere with communication, which shows how effective those children who are bilingual are when communicating in their L2.

Oral and written Tsotsil is used at different events at the focus school, for instance, at their poetry readings under the name of Top Ten Poético, at their festivals and at their school closing ceremonies. Tsotsil is used in all areas of the school such as at the school principal's office, at the basketball court and at the small library they have. The classroom is one of the main sites where Tsotsil is used other than Spanish. It is true that the more students advance through the grades of schooling, the more Spanish they are taught, so their skills in such a language improve; sixth graders are a good example of this. However, students' native language and culture continue to play an active role in the teaching and learning process especially in the early years of schooling. It can be said that the type of bilingualism that students at the focus school experience is additive bilingualism because it involves respect and "the learning of the second language does not portend the slow replacement of it for the home or the other language". As their languages are accepted and valued, students' sense of self and views of their own language are positive and supported (de Jong, 2011, p. 63). The fact that the teacher in grade 3 speaks both languages, but mostly Tsotsil as this is the language better known by the third graders (at this point) also influences the students' language choice. It should be mentioned that the fact that students at the research school are allowed to use Spanish and Tsotsil and are taught in both languages contributes to the creation of an inclusive environment at the school which is essential for learning to take place.

\section{CONCLUSIONS}

Education as a Tool to Create a Harmonious Society

Education can be a double-edged sword. In other words, it can be used as a powerful tool to help or as a weapon to destroy. This depends on the purpose education has and how it is used. For example, when education is implemented to violate the cultural and linguistic human rights of indigenous children, it can be said that education acts as a weapon. On the contrary, when education is used to respect, preserve and promote children's native language and culture and enrich them with another language, Spanish in this case, it can be said it is a powerful tool. In other words, when education promotes additive bilingualism, that is, when it is used to strengthen cultural and linguistic diversity is when it is possible to say it has accomplished its real goal. 
Education, for example, quality bilingual education is a vital tool to maintain and promote indigenous languages as evidenced by the research bilingual school in Chiapas. Participants have taken an active role to preserve and strengthen their native language and culture. They have demonstrated that it is possible to implement quality bilingual education which is essential to maintain the human and intellectual capital for each nation's future (Rodríguez \& Rodríguez, n.d.). The focus school is a good example that cultural and linguistic diversity can be embraced through education. Today more than ever, it is imperative to run schools as caring and inclusive communities where each student feels involved and cared for.

The school should be a real home for each child especially for indigenous children who have historically been discriminated against and their voices have been silenced. This is a situation that may have serious repercussions on their lives as children, but also as adults in the future. As Del Carpio (2017) states "childhood is one of the most important stages in a person's life and what happens during that stage greatly impacts one's future life" (p. 236). This is one of the many reasons that underline the urgency of creating and implementing quality bilingual programs and of building safe, caring and inclusive schools for indigenous children and all children in the world. Yes, quality education and inclusive schools are great tools that can contribute to have a harmonious and peaceful world.

\section{REFERENCES}

[1] Bessant, J. (2013). History and Australian indigenous child welfare policies, Policy Studies, 34 (3), pp. 310-325.

[2] Caminal, R., Cappellari, L. \& Di Paolo, A. (2018). Linguistic skills and the intergenerational transmission of language. Retrieved February $4^{\text {th }}, 2019$ from http://www.iae.csic.es/investigatorsMaterial/a18259122139sp68259.pdf.

[3] Costas, X. (2018). Martin Codax' cantigas in 55 minorized languages. Department of Galician and Latin Philology, University of Vigo, Galicia, Spain.

[4] De Jong, E. (2011). Foundations for Multlingualism in Education: from Principles to Practice, Philadelphia, USA: Caslon Publishing.

[5] Del Carpio, K. (2012). Spanish-Indigenous bilingual education in Chenalhó, Chiapas, Mexico (Published doctoral dissertation). University of Alberta.

[6] Del Carpio, K. (2017). "Tsotsil children and bilingual education in Chiapas, Mexico: The social and academic consequences of considering or not indigenous children's language and culture in education”, pp. 1-267, ISBN: 978-3-659-65833-4, Editorial Académica Española, Spain.

[7] Estadística de Población de Chiapas. (2014). Instrumentos normativos para la formulación del anteproyecto de presupuestos de egresos. Retrieved March 6th, 2016 from http://www.haciendachiapas.gob.mx/marcojuridico/Estatal/informacion/Lineamientos/Normativos/2014/XXIII-Estadistica-Poblacion.pdf.

[8] Francis, N., \& Reyhner, J. (2002). Language and Literacy Teaching for Indigenous Education, Clevedon, England: Multilingual Matters.

[9] Guitart, M. (2006). Identidades culturales. Caminando hacia la igualdad y pluralidad en la Universidad Intercultural de Chiapas [Cultural identities. Walking towards equality and plurality in the Intercultural University of Chiapas]. In Vilá (Ed.), Lengua, interculturalidad e identidad [Language, interculturality and identity] (pp.71-91). University of Girona.

[10] Hernández, J. (2009). Una escuela para la vida: Algunos aspectos de una intervención pedagógica de la UPN en una comunidad indígena. Revista Universitaria de la Universidad Pedagógica Nacional, 8(10), 1-10.

[11] INEGI. (2010). Información de México para niños. Retrieved February $4^{\text {th }}, \quad 2019$ from http://cuentame.inegi.org.mx/monografias/informacion/chis/poblacion/diversidad.aspx.

[12] Lightbown, P. \& Spada, n. (1999). How languages are learned. 3rd edition. Oxford University Press.

[13] López, L. (2009). Reaching the unreached: indigenous intercultural bilingual education in Latin America. Paper commissioned for the EFA Global Monitoring Report 2010, Reaching the marginalized. Retrieved February 3, 2019 from http://unesdoc.unesco.org/images/0018/001866/186620e.pdf.

[14] Reifler, V. \& Edmonson, M. (1984). Handbook of Middle American Indians. Austin: University of Texas Press.

[15] Rodríguez, R. \& Rodríguez, J. (n.d.). Many languages, one nation valuing bilingual children. Retrieved March 23, 2016 from http://www.idra.org/IDRA_Newsletter/February_2008_Quality_Teaching/Many_Languages_One_Nation_Valuing_Bilingual_ Children/.

[16] Villegas, E. (2011). Diversidad lingüística de los pueblos indígenas de México: La existencia de la diversidad en nuestra cultura. Retrieved February 12th, 2015 from http://diversidadlinguisticamxico.blogspot.com/2011/04/lenguas-indigenasexistentes-en-mexico.html.

[17] Woodbury, A. (2012). What is an endangered language? Retrieved on February 2, 2019 from https://www.linguisticsociety.org/content/what-endangered-language-0. 


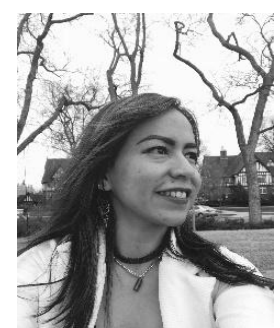

Karla B. Del Carpio is currently Associate Professor in the Department of World Languages and Cultures at the University of Northern Colorado. She earned her bachelor's degree in Teaching English as a Foreign Language from the Autonomous University of Chiapas in Mexico, her master's degree in Applied Linguistics from the Department of Modern Languages and Cultural Studies of the University of Alberta (UofA) in Canada and her PhD in Secondary Education from the Faculty of Education of the UofA. Dr. Del Carpio has won different awards in Canada, Mexico and the United States, for example, she received the 2011 Zita and John Rosen Teaching Award in Canada, the 2013 National Academic Achievement Award in Mexico and the 2020 Humanities and Social Sciences Excellence in Teaching Award in the United States. Her research interests are in the areas of second language acquisition, teaching English as a second language, bilingual education and indigenous languages revitalization. 